\title{
THE INVALIDITY OF THE JUDICIAL NOTIFICATION: IT'S EFFECT FOR THE JUDICIAL NOTIFICATIONS IN THE IRAQ JUDICIAL SYSTEM
}

\author{
Abdul - Jabbar Ali Hammood \\ Ph.D Candidate, Department of Shariah and Law \\ Academy of Islamic Studies \\ University of Malaya \\ 50603 Kuala Lumpur. \\ abduljabbarali50@gmail.com \\ Ruzman Md Noor \\ Associate Professor, Department of Shariah and Law \\ Academy of Islamic Studies \\ University of Malaya \\ 50603 Kuala Lumpur. \\ ruzman@um.edu.my
}

\begin{abstract}
Judicial notification is considered one of the basic principles of a lawsuit, which is to notify the litigants of attendance and the development in the case. Judicial notification may have many problems, the most important of which is the invalidity of judicial notification and the accumulation of cases before the judiciary and lack of seriousness in the attendance of the adversaries to gain time by the defendant, or errors found in the notice paper that invalidate its purpose. The main objective of judicial notification is to ensure the litigant's attendance before the court, and they don't litigant's attendance to the court and the effect of its invalidity and the role of the judiciary in case it is invalidated the judicial notification. This prompted the legislator to oblige the litigants to submit their pleadings for judicial notification prior to making any other pleas or to plea of invalidity of the of judicial notification through setting appropriate standards to
\end{abstract}


reduce the case of invalidity of judicial notification. Which calls the legislator for the need to take an important step to regulate the judicial notification and the invalidity of judicial notification can be corrected to serve the judiciary.

Keywords: judicial notification, invalidity, code of procedure, civil code, the notification memo, procedures of the judiciary

\section{INTRODUCTION}

One of the fundamental functions of the state is the administration of justice among the people. This is done only by establishing and regulating the judiciary. People need the judiciary at all times and places, otherwise, chaos will prevail. Judicial notifications are part of the formal procedures by which the other party is notified of the proceedings to attend before the court. It is the key that judicial disputes cannot be settled without. And that failure to complete these procedures in accordance with the law will delay the resolution of the proceedings until completion of the notification procedures. One of the most important reasons behind the dismissal of the case is the procedure of the judicial notification to the litigants. The adversary must be notified by the statement of claim and all memorandum that can be submitted by one of the litigants, he/she shall also be informed of the judgment, also if the verdict was challenged by a notice of appeal, the appointed day to attend before the Court of Appeal, weather the appeal is challenged. The Appellant (defendant) must be notified by the notice of appeal and other judicial notifications that may impede the proceedings if they are not done properly, and that process may take several months, sometimes one or more years in which the litigant evades the notifications when he/she or his lower feels that the lawsuit will be lost.

This study, which we discuss by the law of the pleadings and researchers, what happened to the law of the pleadings of the amendment of its texts in order to keep up with the developments in the legislative field and to keep pace with the rest of the other legislation.

The basic purpose of the judiciary is to ensure the legal protection of all people. The judiciary is the arena to ensure that justice prevails. Therefore, the judgments must be fair. Besides, it must be quick, complete and cost-effective. To meet the requirements of the justice, so the judiciary represents the holiest and the noblest message, a message to achieve the right and give everyone their rights. It is a refuge for individuals, through punishing lawbreakers and outlaws, and the most important elements of this judiciary is the "the judicial notifications". 
The judicial notification is a formal procedure intended to notify a person of the content of a judicial notification by the court that must be valid to achieve its objective (Adam Wahib al-Nadawi, 1988: 1). If the judicial notification have any defect or deficiency, this will lead to invalidation. Article 27 of the Code of Civil Procedure stipulates that "The judicial notification shall be considered null and void if it's defected or materially incomplete, in a way that violates its validity or its purpose."

\section{LEGAL EFFECTS OF THE JUDICIAL NOTIFICATION}

First, through the judicial notification, many things appear to have positive effects when the notification is true and is in accordance with the legal procedures and the fundamentalist form. Where the attendance at the scheduled time after the notification was in accordance with the law and attendance at the time of the hearing and the proceedings are in the presence of the defendant. As many things appear to have negative effects when the notification is not true as well as when the Judicial notification is not in accordance with the law. If the opponent does not attend at the appointed time and place, the court will be tried the defendant in absentia. Also the court will decide to proceed with the case before it, and whether the judicial notification has been executed according to the law and if it found that it had been done contrary to the provisions of the law or the liability wasn't notified, the court also may find negligence in notifications by the notify person, therefore, the court should punish the notify person by imposing a fine, as stipulated in the Iraqi Code of Civil Procedure, ${ }^{1}$ "The court may by an unchallengeable decision penalize the summoner with a fine not less than (3) Dinars and not exceeding 10 dinars if the voidance (of a procedure) was attributed to his negligence.." The notifying party must get the signature of the other party (notified party) to the lawsuit on the origin of the notice sheet in order to give it an official status. This shall be regarded as a confirmation by other party that it had been notified. Such procedures shall take effect from the time of signing of the court summon notice.

Second, The Code of Procedure stipulated, "Upon delivery of the summon notice to the notified party, his signature shall be taken by signature, stamp or thumbprint as acknowledgment of receipt, on the original copy of the notice and then to be signed by the notifying party and indicating the date and time of notification." The effects of the notice shall also apply in the event that the notified party/parties refuses to do so, whether the failure to get the signature

Article 28 of the Iraqi Code of Civil Procedure.

2 Article 19 of the Iraqi Code of Civil Procedure. 
on the notice or receipt, as the refrain is considered as a notice and its effects will be applied to the adversary.

The Civil Code of Procedure stipulated, 3 " If the concerned person refused to take receipt of the memo, or, as the case may be, by those eligible to be notified, The summoner shall document such a refusal in writing, indicating the time, date, and place thereof, this shall be considered as a notice). The signature on the original paper and its copy or the refusal to sign and receive it shall be considered as the time that determine the beginning of the legal effects, which is the assessment that the court can apply to the case before it (Heba Mohamed Mohsen, 2007: 107).

\section{THE EFFECTS OF THE FAILURE TO COMPLY WITH THE OF JUDICIAL NOTIFICATIONS}

The judicial notification that contradicts the Civil Code of Procedure is considered null and void, as if it did not occur. In this case, everything that contravenes the Civil Code of Procedure shall be null and void, including the notification. This is what was decided by the Iraqi Court of Cassation in another decision that stipulates the following, ${ }^{4}$ "The judicial notification shall be considered null and invalid if it's defected or materially incomplete, in a way that violates its validity or its purpose). This decision is similar to Article (27) of the Iraqi Code of Procedure, which considered that any defect in the elements of the judicial notification or if its procedures contradicts the Code of Procedure it considered as void and null.

The invalidity of the judicial notification is relative. It can only be applied to cases protected by the law. Examples of errors and shortages that lead to the nullity of the notification are not knowing the name of the court, the defendant or the date of the pleading. The court must check the notice sent to the party who failed to attend, to verify the validity of the notification that was addressed to him/her, it determines the invalidity of the notification and the renewal of the notification if the court considers that its deficiency is substantial (Sadiq Haidar, 2001: 48). Accordingly, the decision by the Federal Court of Cassation "after scrutiny and deliberation, it was found that the challenge for cassation took place within the legal period and the court is able to affirm the cause of action in form. The discriminatory provision was found to be invalid and illegal. because the court of first instance and the court of appeal invoked the notification of the defendant's daughter. The court dismissed the challenge

\footnotetext{
3 Article 20 of the Iraqi Code of Civil Procedure.

4 Decision No. 671/Shariah/970 on 19/3/1970, 15, the legal principles of the Court of Cassation, Prepared by Ibrahim Almahahdi, former source, 114.
} 
in form because of its occurrence not within the legal period. This decision was supported by the Court of Appeal without taking into consideration the conditions of notification according to the Article 16 of the Civil Procedure Code that the court summon notice shall include several information about the notified party such as name, job/profession, domicile and the name of the person who received memo 's copy, his/her capacity and signatur, his capacity and signature on the original, or, as the case may be, indicating his decline to sign off. and reason of the decline the if any. In reference to the summon notice of the judgement in absentia it was found that it included only the name of the notified party and did not include his profession and his place of residence, and did not include the full address of the house, that make the notifying party statement invalid, as it is likely that he has gone to another house, and that the daughter, to whom the notifying party referred, who decline to sign the notice, her name was not mentioned in the statement on the summon note. Thus, the judicial notification adopted by the court didn't fulfill the legal requirements and is considered to be void because of substantial deficiency. ${ }^{5}$

\section{THE INVALIDITY OF THE JUDICIAL NOTIFICATION}

The invalidity is one of the most important procedures, and there is no other procedure that is superior to it in terms of importance. It is the only measure that the opponent fears to be challenged.

\section{DEFINITION OF INVALIDITY}

The Iraqi legislator stipulated in the Article 27 of the Code of Civil Procedure "The judicial notification shall be considered invalid if it's defected or materially incomplete, in a way that violates its validity or its purpose." invalidity defined as a procedural sanction: a description of the procedural action that has failed in one of its elements or one of its validity conditions and prevents its legal effects even if the procedural action was valid (Mahmoud Mohamed Hashim, 1981: 184).

The Egyptian legislator ${ }^{6}$ say, the notification shall be null and void, if the action does not achieve its purpose and the notification in the Malaysian Procedural Law is similar to the Iraqi law. ${ }^{7}$

5 Discriminatory Decision No. 1632/The Appeals Board, reported in/2011 on 26/10/2011 (unpublished).

6 Article 20 Egyptian Code of Procedure.

7 Shariah Court Civil Procedure (Federal Territories) Act 1998 (Act 585). 
As the Lebanese, ${ }^{8}$ French ${ }^{9}$ and Jordanian legislators ${ }^{10}$ said, it cannot be said that the notification is void and its declaration is void because there is a defect in the form, and in the case that there is a Damage, the Damage is the failure of the interest that the law intended to protect and preserve.

There are many views regarding the definition of invalidity. One of these views is that the invalidity is a legal adaptation of any act that contravenes its legal model and that leads to the inability to produce the effects that the law can have if it is valid (Fathi Wali, 1959: 7). The invalidity is the penalty resulting from violating the formalities of the judicial procedure (Ahmed Muslim, 1966: 206). others define invalidity as. It is the penalty determined by the legislator against violating the rules contained in the procedural texts that determine the required procedures and forms (Amina Mustafa Al-Nimr, 1992: 186). Also, it's the procedure performed by the Court or any of its employees that doesn't lead to any judgment, action or effect, Due to the failure to follow the formalities established by law (Mamdouh Abdul Karim, 1072: 313). All definitions of invalidity despite its variation of the wording have similar context. All of the above shows the lack of respect for the conditions and formalities established by the law, Therefore, the procedures established by law must be respected, not underestimated, and respect and protect the rights of others seriously against violations of the procedures established by law, thus, if the judicial notification has deficiency in its critical data, this will lead to the violation of the validity of the notification and consider it as invalid for violating the legal rules, and this is what was ruled by the Iraqi Court of Cassation. ${ }^{11}$

It should be noted that the invalidity is divided into several types, and as far as judicial notification are concerned, the invalidity is divided into an invalidity related to the public order and the other type of invalidity related to the private interest. This division is one of the most important divisions in which it is possible to identify the impact of each of these types on the actions that respond to them.

The invalidity that is related to the public order, such as the violation of a rule established for the protection of the public interest, in other words those rules relating to public order, such as the rules relating to the judicial system, It should be noted that the invalidity of the public order should always have the primacy whether it was adhered to by those who have interest or not, the

\footnotetext{
$8 \quad$ Article 59 Lebanese Assets Law.

9 Article 114 French Code of Procedure.

10 Article 24 Jordanian Assets Law.

11 Decision No. 611/legal 2/69 on 22 October 1969, 172 within the legal principles in the Court of the Cassation prepared by Ibrahim Mashahadi, 113.
} 
court has to rule in its favor always, in addition to it may not be waived and can be invoked the invalidity that related to the public order at any stage of the proceedings and at any stage of litigation (Wagdy Ragheb, 1978: 86).

The second type of invalidity is related to a private interest. It is a sanction ruled to protect a special interest of a certain person or persons, so that such person or persons shall have the right to invoke invalidity (Abdulbaset Jahmi, 1980: 498). The invalidity of the private interest may be invoked only by the opponent who the invalidity is in his favor, which has been called relative invalidity. Moreover, the invalidity that is related to the private interest may not initiated by the court on its own, contrary to the invalidity of the public order, it is a private matter exercised by the individual whenever necessary. Referring to the invalidity of judicial notifications, we find that they invalid in relation to the private interest, Since the provisions of judicial notifications relate to the interests of the litigants and are primarily established for the provision of adequate safeguards so that they are aware of the legal actions taken against them. For example, notifying one person of the notified parties without the others required or the date of their notification notice sheet is different regardless of the law, is considered defective and the failure to comply with the requirements of the law that leads to one or all of them have the right to plea for the invalidity as a personal right exercised by the individual if he desired and in this sense is a relative right and not an absolute right. An example is the decision of the Iraqi Court of Cassation" "if the date of notification which is stated on the first copy of the notice is different from the date on the second copy of the notice, the notification shall be considered invalid and the discrimination have occurred prior to notification".

As noted above, the judicial notification is Improper and contrary to the law if it was defected or incomplete that makes it misses it purpose and therefore it is considered invalid. In other words, if the notification is deficient in one of its essential statements, this leads to a violation of the validity of the notification and is considered null and void for violating the legal principles. On this basis, the Iraqi Court of Cassation ruled in a decision stating the following: ${ }^{13}$ "The legal notification that is contrary to the Law of Procedure is considered invalid". It shall be noted that any notification that contravenes the law of procedure shall be null and void, including judicial notification.

12 The discriminatory decision no. (284)/First the Syariah Court/1973 on 27 May 1973 referred to by Ibrahim Al-Mashahadi, the Legal Principles, previous source, 117.

13 The discriminatory decision No. 611/Second Court/69 on 22 October 1969, 172, cited by Ibrahim Al-Mashahadi the legal principles of the Court of Cassation, 113. 


\section{CASES OF INVALIDITY OF JUDICIAL NOTIFICATION}

According to some jurisprudence, the defect in a notification means that its method is subject to a violation of the conditions or requirements stipulated by the law as violation of the provisions of the allowed time for notification and the manner of hand over the notice sheet and the persons who may be handed over the notice (Ramzi Saif, 1964: 453) and others see not to expand the interpretation of the term flaw in notification, because the meaning of this phrase is (flaw in the method of notification) as if the notice was handed to a relative of the concerned person in his domicile without even if he/she doesn't live with him or the notice memo doesn't have the on name and the signature of the persons who has been handed over to (Ahmed Abu Al-Wafa, 1957: 310). The invalidity of the notice shall result in the nullification of all previous proceedings and the consequences thereof. This is what was decided by the Federal Court of Cassation. "The notification shall be invalid if the notifying party stated that he has found the house closed and stuck the notice sheet on the door of the house. Because sticking the notice sheet on the door of the house is correct when the to the concerned person is in the house and refuse to hand over the notification. The invalidation of the notification invalidates the subsequent proceedings, whatever is based on invalidity is inevitably also invalid." ${ }^{14}$ The Court of Cassation ruled in another decision "if the court has held the proceedings in the lawsuit without notofying the defendants, the legal proceedings are invalid because the notification is incomplete for this the case) (Khalid Mohammed Jalal al-Araji, 2015: 31). The invalidity of the notice shall result in the invalidity of most of the procedural actions that follow, and therefore all other applications and defenses shall be null and void in accordance with the invalidity of the judicial notice sheet (Fathi Wali, 1973: 403).

\section{PROCEDURES OF THE JUDICIARY ON INVALIDITY}

The judiciary takes two directions on the invalidity as follows:

Firstly, it is well known that all courts, especially the Court of Cassation and its general jurisdiction, including the right to control the proper functioning of laws, and therefore have the right to quash a judgment if the notification is defected or materially incomplete, in a way that violates its validity or its purpose. Practical applications of the Court of Cassation include:

14 The discriminatory decision No. 308/Civil court/2014/19/5/2014, Khalid Mohammed Jalal Al-Araji, former source (publication), 31. 
1. The notification shall be considered invalid if the name of the person who has been handed the notice on behalf of the concerned person because he/ she refused to be notified, is not mentioned with the requested person, whether the person is with him in his place of residence or in his place of work, since just writing down the refusal without mentioning the person's name is not sufficient and that's make the notification invalid. This is what the Court of Cassation has ruled and stated as follows: 15 "The notification shall be invalid if the name of person who was handed the notification and the concerned person who refuse to be notified are not mentioned,)

2. To inform a relative of the opponent residing with him requires that the opponent necessarily reside with the person that has been notified on his behalf on that same day. This means that if concerned person is absent from his place of residence, such as traveling, then the notification of one of his relatives may have a fundamental defect in a way that violates its validity or its purpose. Therefore, the notification is invalid according to the provisions of Article (27) Of the Iraqi Code of Civil Procedure, that is, the law requires cohabitation for the relatives of the concerned person, not just the status of kinship, and pursuant to what was ruled by the Court of Cassation. ${ }^{16}$ "the permissibility to notify one of the relatives of the adversary residing with him shall require that such opponent be resident with the person on whose behalf the notice is delivered.'

3. In a decision of the Court of Cassation, in which it ruled that "If the notified opponent or his agent does not attend on the appointed day of the proceedings or does not submit their notice for not attending, before the day of pleadings, the second opponent have the right to plea for the dismissal of the lawsuit, the dismissal plead is shall not be invalid even if a telegram of the attorney of Plaintiff (the opponent) was received to request for rescheduling in the following day the pleading or the arrival of the plane of the agent of the opponent from Baghdad to Basra, was delayed, which did not attend the hearing, as long as the court did not receive this notice

15 Decision of the Iraqi Court of Cassation No. 1844/Fourth Civil court/1975 on 10 November 1976, group of judicial verdicts/the fourth issue/the seventh year/976, 182, Legal principles if the jurisdiction of the Court of Cassation, prepared by Ibrahim Mashahdi.

16 Decision of the Iraqi Court of Cassation, No. 858/Third Civil Court/1971 on 9 February 1977, Collection of Judgments, first issue, ninth year, 1977, 123, Legal principles of the jurisdiction of the Court of Cassation, prepared by Ibrahim Mashahdi. 
before or on the day of the pleading." ${ }^{17}(26)$. It is noted that the Court of Cassation ruled that he did not take into consideration the time for the flight between Baghdad and Basra, even if the means of transport that took off the opponent or his agent, the plane, there are complex procedures in travel such as booking and others that may require more time to reach destination, leading to delay the opponent and his agent to the court, And consequently to the ruling of the Court of Cassation for invalidity simply because they did not attend on the day of the hearing.

4. In another judgment of the Court of Cassation of Iraq ruled that "the sister of the plaintiff can't be notified if she lives in another city even if the plaintiff has temporarily living with her". ${ }^{18}$

5. If the appointed day of the pleading of was a public holiday and the court appointed another day to plead, the opponent must be notified, and the opponent may not be considered notified on the grounds of the presence of his attorney to other pleading in the same court on the same day or because he did not pursue the case of his client after the public holiday. ${ }^{19}$ It is noted in this provision that if the court does not set a date for the pleadings, the working day after public holiday shall be regarded as the next day. The attorney shall be considered notified by his knowledge of the provisions of the Law of Pleadings. The burden of delivering the notification to his client shall be on him/her. If the court sets a date for pleading after the public holiday, he shall pursue the case of his client, and the court must notify him/ her of this new date.

6. In the decision of the court of Appeal of Babel, "it is evident that the defendant's address in the notice of action shows that she is a teacher in the (C) primary school for girls. Therefore, the place of the defendant in this case is the school, as required by the rules of justice, is the department in which she actually work (i.e. the school, not the Directorate General of Education) the notification of the decision to the court General Directorate of Education, not the school, shall be deemed inadmissible by law and just because the arrival of this decision to the defendant may take a long time between the receipt of notification from the Directorate General of

17 Decision of the Court of Cassation No. 511/First Civil Court/1976 on 28 December 1976, Collection, fourth issue, the seventh year, 216, Legal principles of the jurisdiction of the Court of Cassation, the previous source, prepared by Ibrahim Mashahdi.

18 Decision of the Iraqi Court of Cassation, No. 1526/court/1975, 17 November 1975, Collection of Judgments, No. 4, Sixth Year, 1975, 103, Legal principles of the jurisdiction of the Court of Cassation. prepared by Ibrahim Al Mashahdi.

19 Decision of the Iraqi Court of Cassation No. 540/court/1975 on 13 July 1975, Collection of Judgments, No. 4, Sixth Year, 1975, 116, Legal principles of the jurisdiction of the Court of Cassation, prepared by Ibrahim Al Mashahdi. 
Education to the school in which she works in and therefore decided to dismiss the discriminatory provision. ${ }^{20}$

7. The Iraqi Court of Cassation also decided in another ruling, "if the plaintiff is not properly notified of the contested decision, the decision to dismiss the action shall be contrary to the law and which shall be considered invalid). ${ }^{21}$

8. Also ruled that, if the court did not confirm that the notification of the judicial documents to one of the parties to the lawsuit residing in an Arab country, weather it has acceded Agreement on the implementation of judgments between Arab League countries signed in Cairo in 1952 and the ratification of this country to the Riyadh Convention in 1983, its judgment shall be subject to appeal. ${ }^{22}$

9. It is not sufficient it was not sufficient to file a notification to the absentee employee that he must be attend to his place of business, in his registered mail, however, article 14 of the Code of Civil Procedure sets forth the method to deliver thee notification by registered mail and stipulated that the signature of the applicant to be notified on the memo and to be posted back by the Postal Service to the department requesting notification, as the Iraqi Court of Cassation ruled the following: ${ }^{23}$ "The notification by registered mail shall not be considered unless the person to be notified have sign that he/she was notified on the notification's memo then to repost it by the Postal Department to the of the department requesting notification."

10.In another ruling of the Iraqi Court of Cassation, in which it stated, "if the concerned person refused to be notified.", and the notifying party stated that in his statement explaining "the concerned person has refused to be notified." This is not considered a valid notification in accordance with article 20 of the Iraqi Code of Procedure, unless notifying party clarifies that the concerned person to be notified has refrained from receiving the notice. ${ }^{24}$

20 Decision of the Court of Appeal of Babylon No. 59/Rights/1979 on 21 December 1979, published in the Iraqi Judicial Proceedings No. 12, 115, referred to Adam Wahib al-Nadawi, a former source, and Heba Mohammed Mohsen, a former source.

21 Decision of the Court of Cassation/First/86/1987 on 30 August 1987 (unpublished).

22 Decision of the Court of Cassation No. 347/First/No. 364/85/1985 on 31 March 1987 (unpublished). Referred to by Ali Guma Muharib. And Heba Mohamed Mohsen, a former source.

23 Decision of the Iraqi Court of Cassation, No. 13, General Assembly 85-86 on 18 August 1985 (unpublished).

24 Decision of the Iraqi Court of Cassation issued on 17 June 1984 published in the Journal of Judiciary issued by the Bar Association of Iraq, the third and fourth issue, the ninth year, 1984 . 
Second, the adopted procedures to limit cases of invalidity of notification, aimed at reducing cases of postponement of the lawsuit.

Among the applications of the Iraqi Court of Cassation in this regard, we state the following:

1. If the pleading has taken place in the presence of the plaintiff, the sentence against him shall be deemed in his presence and there is no need to notify him. This is what the Court of Cassation has ruled by stating, "At the examination and deliberation It is found that the proceedings was conducted in the presence of the defendant, before the Court of First Instance based on the presence of his attorney $(\mathrm{M})$, before it in a number of sessions, the challenged judgment issued against him in this situation in his presence in accordance with the provision of Article (161) of the Code of Civil Procedure and there is no need for this reason to notify him..$^{25}$

2. In another ruling, the Court of Cassation ruled that, " the proceedings is considered to be in-presence if the litigant is present at any session, even if he is absent in other sessions in accordance with the first paragraph of article 55 of the Civil Procedure Law, and since the attorney was present before the decision was taken The prosecution is considering the case is postponed, the pleading is considered to be is present If he is absent in other sessions, and the judgment in the case shall be in his presence, and the description in which the court describes this judgment not taken into account, but rather the rule of law must be followed in this case. ${ }^{26}$

3. The defendant is considered notified of the challenged judgment from the date of submission of the discriminatory petition to the Court of Cassation if he/she was not notified before that date. ${ }^{27} \mathrm{~A}$ reference to the above, it has been defined by some as a legal adaptation to a legal action contrary to its legal model in a manner that leads to the failure to produce the effects determined by the law if it was complete (Fathi Wali, 1973: 403). The invalidity is established in the Egyptian Code of Civil and Commercial Procedure in Articles $(24,25,26)$, where the Egyptian legislator considered that the procedure is invalid if the law provides for nullification.

25 Decision of the Court of Cassation No. 34/Civil First/82 on 21/5/1982, Journal of Judgments, No. 2, 1982, Ali Jumaa Muhareb Former source, 24. Hiba Muhammad Mohsen, former source, 114.

26 Decision of the Court of Cassation No. 163/Appeal/1987-1988 on 18/11/1987 (unpublished).

27 Decision of the Court of Cassation No. 945/Civil Fourth/1980 on 2/12/1980 Group, 34, Legal principles of the jurisdiction of the Court of Cassation, Prepared by Ibrahim Mashahdi, 1990. 


\section{MOTIONS FOR THE INVALIDITY OF THE NOTIFICATION MEMO}

The legislator stipulated that failure to follow the legal conditions of the notification notice and if did not include one of the substantive statements in a way that generates a fundamental defect or deficiency in the notice sheet. This is what the defendant will uphold to against the judge, who can submit it as a formal challenge for the invalidity of the notification (Saied Abdul-Karim Mubarak, 1984: 111) as in the following:

\section{The Plea (defenses)}

The Iraqi legislator ${ }^{28}$ has defined the plea as a challenge presented by the defendant to rebut the plaintiff's claim, whether in whole or in part, if the appeal was for a part of the case. Some of the jurist define it as defense motion by the defendant or his attorney to challenge the lawsuit against him and invalidate the plaintiff's claim (Muhammad Shafiq al-Ani, 1963: 55). And the plea represent the other side of the judicial claim, as the legislator recognize the plaintiff the pursue to claim rights, by instituting a lawsuit against his opponent, at the same time provided a way and guarantees to the defendant to challenge it. This has achieved a balance between the parties to the case and that means that the defendant intended to avoid a verdict in favor of the plaintiff without claiming his/her rights in the case

The plea requires the condition of interest. This means that malicious defenses cannot be accepted and the defenses that are not related to the existing dispute or any part of it to rebut the plaintiff's case. ${ }^{29}$ Defenses are divided into several types, substantive objections, challenge the admissibility of the case and formal defenses.

First, substantive defenses (meritorious): are the defenses that are related to the subject matter of the lawsuit, it is the means used by the defendant to prove that his opponent's case is illegal, it's related to the basis of the case and its merits. To be accepted by the court the plea should challenge the defendant to rebut the plaintiff's claim, whether in whole or in part. Examples include the plea of repayment of the debt claimed in the case of repayment, discharge,

\footnotetext{
28 Article (8/1) of the Iraqi Code of Procedure No. 83 of 1969.

29 Decision of the Court of Cassation, Abdulrahman Al-Alam, Explanation of Civil Procedure Code No. (83) of 1969, Al-Ani Press, Part I and II, 110.
} 
Release or Clearing ${ }^{30}$ These substantive defenses must satisfy the requirements of the lawsuit in terms of adversity, suitability and interest.

Second, plea of inadmissibility, it's includes a plea from the defendant to dismiss the plaintiff's claim due to the failure to establish its general conditions. It have several types such as the plea that the party has no capacity, the plea exceptio rei judicatae, the plea of limitation. the plea that the time limit to submit challenge by objection or by appeal has expired, the plea that the due date for dept payment is not yet due. This kind of defenses is considered the middle of the substantive and the formal defenses, as they are like the substantive objections because if the court establish them that would end the dispute, on the other hand as they can't be dismissed unless waived explicitly or implicitly. Because it is related to public order and they are like formal defenses because they do not address the right that is the subject matter of the case.

Third, formal defenses: These defenses are directed against the proceedings of the lawsuit or the jurisdiction of the court, without prejudice to the identity or Plaintiff's right or how the plaintiff protects his right (Medhat al-Mahmoud, 1973: 18). It is intended from these defenses that the opponent challenges the illegality of the proceedings before entering into the basis and subject matter of the case. The purpose of these defenses is to obstruct the process of the case since it is not exposed to the origin of the substantive right or the means that protects the plaintiff's right but is challenged the invalidity of one the opponent actions such as Motion for the Invalidity of The Claim Memorandum.

Examples of formal defenses, such as the Lack of territorial jurisdiction appeal and the invalidity of the notifications. It can be a formal motion relating to public order, such as the pleas of lack of functional, qualitative jurisdiction the court shall of its own motion rule that it lacks competence, even if the litigants do not plead. As for the difference between the three types of defenses is that, if the court decides to dismiss the case based on a substantive defense and the verdict has been decided, then the plaintiff can't file a second claim for the same right, the decision of the court to dismiss the case based on a formal defense, this does not prevent the plaintiff from initiating a second lawsuit if he

30 Ibra': (Release) A science of jurisprudence, a jurisprudential term that comes within transactions, which means release and discharge from liability whether in whole or in part. It is also a legal act that negates the obligation without charge, which is a type of charity. It is applied in Islamic Shariah law, it's established by the sole will of creditors without the debtor's consent. Clearing: defined by the scholars of the Malik, that deduction of debt from another debt. In Jordanian law, paying the sum for the creditor by deducting it from a loan collected from a debtor. 
corrects the procedure that had been challenged. The plea of inadmissibility the case is considered a compromise between the substantive and formal defenses and may be applied in all stages of the proceedings. The judicial notifications are essentially due to the interests of the litigants, because they seek to achieve adequate guarantees for them. Without these notifications, balance between the litigants does not materialize and therefore one of the basic pillars of the litigation process is lost. Any shortcomings in these notifications is a failure for the rights of the litigants.

According to Article (27) of the Iraqi Code of Procedure, when an opponent challenges the invalidity of the notifications, it means that the flawed notifications that has a material deficiency in a way that violates its validity or its purpose.

The position of the Iraqi legislator to compel the opponent to plea for the invalidity of the notifications before any other pleas, that stems from the rule that the opponent is not allowed to resort to this defense at any time, because that will eliminate many steps taken by the court to resolve the case and that will have a negative impact on that case.

The Iraqi legislator stipulated that the formal defenses such as the pleas for voidance of the notification of the pleading or other papers must be made before any other defense, ${ }^{31}$ or the right will be forfeited, and the court will adjudicate it before hearing the subject of the case. this defense shall be included in the petition of defense or appeal or the right will be forfeited. The invalidity shall be nullified if the concern person or his representative attends on the appointed day.

This plea, which is mentioned in the above article, is one of the formal defenses, as mentioned, is against to the dispute procedures, which Article (47) requires to be notified to the opponent in accordance with the procedures outlined in Articles (13) to (27), if it is proved that there it is defected or materially incomplete, in a way that violates its validity or its purpose as in Article 27 of the Code of Proceedings. Such plea shall be made by the opponent before any other defenses or request. If he/she makes any other defenses before, if any other defense was submitted whether in formal or substantive, the right to such a plea shall terminate. if it was proceeded by any other plea, the concern court should settle it before the subject of the lawsuit, whether the court adopted the plea After investigating its validity or dismiss it. However, despite the invalidity of the notification, it shall be nullified if the concern person or his representative attends on the appointed day for the pleadings, if

$\overline{31}$ Article (73/1, 2 and 3) Iraqi Code of Procedure. 
the opponent did not attend at the appointed time but sent a petition to the court on the appointed day for the pleadings, including the plea of the invalidity of the notification. In this case can the court to consider this plea to serves as a presence that corrects the invalidity? The Court shall be bound by the investigation and adjudication, and the opponent can submit this plea by the to the notice memo that is reposted to the Court. If the opponent fails to attend and didn't submit a plea on the returned notice memo, is it permissible for the court to investigate the validity of the plea? It is agreed that the court may examine and verify the validity of the notification addressed to the opponent, whether it is the presence of the plaintiff or the prosecution or other papers. This opinion is supported by Article 51 of the Code of Procedure, which requires the court to verify the completion of the process of notification. This means that the court shall verify the reposted notices, to find out who was notified of the litigants and who wasn't, to establish the legality of the notification or the illegality regarding those who have been notified and didn't attend, then to take the procedure of pleading in absentia or to be remodified if it was not carried out in accordance with the law.

So, for example, one of applications to the Iraqi Court of Cassation and the ruling of the Ninewa District discriminatory Court of Cassation, "After scrutiny and deliberation, when considering the case, it was found that it focus was on the notification procedures of the pleading in absentia and that the appointed day for the pleading is less than three days from the date of the notification, and because the plea in question shall be indicated in the objection or appeal pleading, otherwise the right to it shall terminate, pursuant to Article $73 / 2$ of the Civil Procedure Law. As required by Article 209.3 of the said Law, no new pleas or evidences may be filed to the court of cassation. Therefore, the cassation pleading was lacking the required grounds of challenge, so the court dismissed the pleading in pursuant to the provisions of Article 210/1 of the above-mentioned law and the Plaintiff shall pay the fees..." Due to Iraqi legislator's desire to limit the effects of invalid procedures in judicial action such as legal notifications. It adopts the means of correction as a method to reduce the adherence to invalidity and its effects that may hinder the proceedings, the legislator considered that plea of invalidation of judicial notifications shall be void if the concern person or his representative attends on the appointed day for hearing the case..$^{33}$

Based on the foregoing, we believe that Iraqi legislator position regarding the notifications of the defenses was correct, including the obligation of the

32 The discriminatory decision No. 446/BP/2002 of 12 November 2002, unpublished.
33 Article (73/3) The Iraqi Code of Procedure No. 83 of 1969. 
parties to submit their defenses for the notifications before any other pleas or to limit the resort to the pleas of invalidity of judicial notifications through the development of standards to reduce the case of invalidation of notifications.

The Iraqi legislator has not regulated an integrated theory of invalidity in the same manner as the rest of the legislations. Rather, the rulings of invalidity are scattered in the context of the law of pleadings, which calls for the necessity of taking an important step to regulate this issue. The Correction of invalid actions and procedures, including judicial notifications is worthwhile. and the invalidity of notifications can be addressed in a proper way corresponds to the importance of this issue.

\section{DISCUSSION AND CONCLUSION}

That the judgment of the of judicial Invalidation a clear effect on the detriment of the adversaries, it is possible that the invalidity of judicial Invalidation may be due to the applicant's fault in the full definition of the person to be notified, this error results in the invalidity of the judicial notice and thus the damage to the opponent. Or the liability of the notifying person if the invalidity results from a fault or shortening resulting from error or negligence in the performance of the function, In accordance with article 219 of the Iraqi Civil Code, or because of the notifying person don't check the person who received the notice its him or not to observe the time and places designated for the notification procedures, which are substantial errors resulting in the invalidity of such judicial, here the state is responsible considered as one of its users, and then does not prevent the imposition of a fine for the material damage suffered by the loss of or lost the time, and here we believe that the development of general rules invalidity judicial in the law of pleadings is worthy of attention and care, were not in the law for the repairing of invalidity judicial were not inaccuracy but came scattered and calls for the need to regulate the issue of invalidity in a more precise manner consistent with its importance and its prominent role in resolving the case.

\section{REFERENCES}

Abdulbaset Jahmi (1980). Principles of Pleadings. Cairo, Egypt: Dar Elfikr Elarabi.

Adam Wahib al-Nadawi (2003). Civil Proceedings. Baghdad, Iraq: Al-Sanhury.

Adam Wahib al-Nadawi (1988). "The Importance of Time in Judicial Proceedings," A Study Presented at the Legal Symposium held at the Faculty of Law, University of Baghdad, on 23 April 1988. 
Ahmed Abu Al-Wafa (1957). Theory of Defenses in the Civil Procedure Code. Egypt: Dar-Almaarif.

Ahmed Muslim (1966). Civil Judiciary Law. Beirut: Dar al-Nahda al-Arabiya. Amina Mustafa Al-Nimr (1992). Laws of Pleadings. Alexandria: Monchaat Al Maaref.

Fathi Wali (1959). Theory of Invalidity in the Law of Pleadings. Alexandria: Monchaat Al Maaref.

Fathi Wali (1973). Civil Judiciary Law. Cairo, Egypt: Theory of Impurity.

Heba Mohamed Mohsen2007) ). Notifications and Judicial Cooperation in Iraq. Iraq: Al-Nahrain University.

Khalid Mohammed Jalal al-Araji (2015). Legal Principles in the District Court of Cassation and Disciplinary Courts of Cassation. Iraq, Baghdad: AlSabah Library.

Mahmoud Mohamed Hashim (1981). Civil Judiciary Law. Cairo: Dar Elfikr Elarabi.

Mamdouh Abdul Karim (1072). Explanation of the Iraqi Code of Civil Procedure. Baghdad: Al-Azhar.

Medhat al-Mahmoud (1973). Explanation of the Code of Civil Procedure. Baghdad: Al-Ani.

Muhammad Shafiq al-Ani (1963). Principles of Pleadings and Jurisprudence in Islamic Jurisprudence. Baghdad: Dar al-Arshad.

Ramzi Saif (1964). Al-Waseet in Explaining the Civil and Commercial Procedures Law. Cairo: Dar Al-Nahda Al-Arabiya.

Sadiq Haidar (2001). Explanation of Civil Procedure Law: Comparative Study. Baghdad: Al-Sanhoori Library.

Saied Abdul-Karim Mubarak (1984). Civil Proceedings. Iraq: Al-Mosel University.

Wagdy Ragheb (1978). Principles of Civil Debate. Cairo: Dar Elfikr Elarabi.

\section{List of Statutes}

Egyptian Code of Procedure.

French Code of Procedure.

Iraqi Code of Procedure.

Jordanian Assets Law.

Lebanese Assets Law. 
The Invalidity of the Judicial Notification

Shariah Court Civil Procedure (Federal Territories) Act 1998 (Act 585). 
Journal of Shariah Law Research (JSLR) 